Forthcoming in J. Haubold, J. Steele, and K. Stevens (eds.), Keeping Watch in Babylon:

from Evidence to Text in the Astronomical Diaries, Boston: Brill (2019)

\title{
Who Wrote the Babylonian Astronomical Diaries?
}

\author{
Eleanor Robson
}

The Babylonian Astronomical Diaries comprise the longest-running and perhaps most important observational dataset from the ancient world. ${ }^{1}$ Yet we still know very little about how they were made. Who wrote the Diaries? Who collected, organised and compiled the data they contain? Who made the manuscripts that have come down to us, whether originals or copies? These questions are surprisingly difficult to answer. As Alice Slotsky has pointed out, only six Diary tablets have even partially surviving colophons giving information about the circumstances of their production. ${ }^{2}$ Yet the surviving manuscripts may be decades or even centuries younger than the original from which they were copied. ${ }^{3}$ As for the collection of the data, the clearest evidence comes at the very beginning and end of the tradition: letters and legal documents give testimony of individuals making celestial observations in the mid-seventh and late second centuries BCE. But each of these data sets raises questions about the extent to which they can be generalised.

1 This paper draws on research carried out for the Geography of Knowledge project (http://oracc.org/cams/gkab), 2007-12, funded by the UK Arts and Humanities Research Council (AH/E509258/1), and during an Alexander Humboldt Foundation Bessel Forschungspreis 2011-12. I warmly thank GKAB project members Marie-Françoise Besnier, Philippe Clancier, Graham Cunningham, Frances Reynolds, Steve Tinney and Greta Van Buylaere and the Department of History and Philosophy of Science, University of Cambridge; and express particular gratitude to Professor Stefan Maul, my host in Heidelberg. 2 Slotsky (1998: 99-103): AD -372A: "[Bel?]-uṣuršu, son of Nabu-uballissu" (Artaxerxes II 32); AD -361: "hand of Uballissu-Bel, son of Bel-apla-[iddin]" (Artaxerxes II 43); AD -324A: "From [...]-Bel, son of Mušallim-Bel [...]" (Alexander III 12/6); AD -321 "From(?) [...] Bel-apla-iddin, son of Mušallim-Bel, descendant of Mušezib, which he wrote for his good health, which was copied (from) the property of [...]" (Philip 2); AD -281A: "[...] Bel-uballiț" (SE 30); AD -261C: “[...] ditto, son of [...]" (SE 50).

3 Oelsner (2000: 805). For instance, the word "from" in the colophon of $A D-324 \mathrm{~A}$ and the explicit copying statement in $A D-321$ (see note 2 above) suggests that these are not originals. 
At one end of the chronological spectrum, even though we can identify the men who reported their celestial observations to the Assyrian king (as discussed further in Section 1), this network predates the crystallisation of the Diaries as a genre by $5^{0-100}$ years and is focused on Nineveh, not Babylon where the Diaries originated under a new political regime. At the other end, the Parthian evidence (analysed in Section 4 below) clearly shows a selfgoverning community, based in Marduk's temple in Babylon, deciding which members are fit to observe, record, and calculate, and what their remuneration should be. Those men identify as țušar Enūma Anu Ellil, literally "scribes of (the celestial omen series) 'When the gods Anu and Ellil", a term which is generally, if inaccurately, translated into English as "astrologers". ${ }^{4}$ It would be nice to think that this was the professional label that all diarists used to describe themselves and, in the absence of any evidence to the contrary, it has usually been assumed that this is the case. But, as we shall see, we are up against the hard facts that, as Rochberg (2004: 220) notes, until the Hellenistic period we have precious little evidence of individuals using the title țušar Enūma Anu Ellil, and that none of that evidence comes from surviving Diary manuscripts, nor precious few copies of Enūma Anu Ellil itself.

So where do we go from here? First, it is important to distinguish the compilers of the Diaries — I shall call them the diarists — as only one small subset of the people with an intellectual interest in the movements of the heavenly bodies in the first millennium BCE.

The largest group was surely made up of those who watched the night skies on a regular basis, whether for divinatory or calendrical purposes. We can almost certainly count a significant proportion of the adult population amongst these observers, for years and months began with the sighting of the new moon at sunset, in both civic and religious calendars. Further, many people observed taboos on certain days of the lunar month, and some months of the lunar year, as laid out in hemerologies and menologies such as the socalled Babylonian Almanac and Iqqurīpuš, "He destroyed, he built". ${ }^{5}$ Then, as zodiacal astrology gained currency in the course of the fifth century BCE, therapeutic interventions such as medical treatments and ritual performances were increasingly tied to which constellations were currently visible in the night sky. ${ }^{6}$ Some observers may have noted what 4Cf. Rochberg (2004: 219).

5 See Livingstone (2007; 2013); Lauinger (2016) for editions and explanations of these compositions.

6 Heeßel (2008); Wee (2016). 
they saw for their own use, but only a small subset can have been reporters - people who formally and systematically described their observations in writing, whether for an external client such as a king or for long-term personal, familial or community use. Some of these reporters, such as the scholars associated with the Assyrian court, wrote reports of single events; others, such as the diarists, made much longer compilations, in a process that we are only now beginning to understand. ${ }^{7}$

As we shall see in Section 1 below, reporters to the Assyrian king were based in half a dozen cities of Assyria and Babylonia. However, as John Steele has demonstrated, in postAssyrian Babylonia, the diarists almost certainly resided only in Babylon itself, where they or others also produced secondary compilations of celestial observations. ${ }^{8}$ Strictly speaking, then, our quest should focus exclusively on that city. However, there were also significant numbers of scholars who used data and compilations extracted from the Diaries (or their precursors) in other cities, including Nineveh, Nippur, and Uruk. A further tranche of tertiary works, derived in turn from the secondary compilations mentioned above, are found in Nippur and Uruk as well as Babylon. Most useful for our purposes are the Horoscopes, from the late fifth century onwards. ${ }^{9}$ So we should consider the identities of their consumers too. We can find traces of all four groups-observers, reporters, consumers, and the diarists themselves-right up until the end of the cuneiform tradition in mid-first century BCE Babylon. $^{10}$

As the evidence covers some seven centuries, and drastically changing political circumstances, it will be helpful to periodise the discussion. For our Babylon-centric purposes, we shall treat the Neo-Assyrian period as beginning with Sargon II's conquest of

7 Mitsuma (2015).

8 Steele (2016: 91-100). From the early fourth century BCE onwards these included lists of lunar eclipses, planetary phenomena, and solar eclipses, and from the mid-third century Goal Year Texts, which predicted a range of key celestial events in a given year, based on their regular occurrences in years past. See Hunger (1999) for a useful summary of these genres and their relationships.

9 From the early third century BCE there were also month-by-month predictive texts now known as Normal Star Almanacs, and Almanacs from the late third century, both probably compiled from data in Goal Year Texts (Gray and Steele 2008).

10 I shall not attempt to address the last vestiges of cuneiform scholarship in the first century $\mathrm{CE}$, which comprised merely a few "badly trained scribes composing simple Almanacs and Goal Year texts in bad cuneiform" (Brown 2008: 94). 
Babylonia and ending with Nabopolassar's declaration of independence, 709-627 BCE. The succeeding period of self-government, it is now commonly agreed, transitioned relatively smoothly into the early years of Persian rule for most Babylonian institutions, and for that reason we shall treat the Neo-Babylonian and Early Achaemenid periods together as the Long Sixth Century, 626-485 BCE. The Late Achaemenid era, beginning early in the reign of Xerxes and ending with the conquest of Alexander the Great, thus runs 484-331 BCE. Finally, I shall take the Hellenistic period to include the reigns of Alexander and his immediate successors, as well as those of the Seleucid kings, 330-141 BCE, plus the first century or so of Parthian rule over Babylonia, during which time the dateable cuneiform record finally peters out in Babylon in the final decades BCE. For each period, I shall attempt to answer the following questions:

- Who recorded celestial observations, whether in single reports or compilations?

- How did they describe themselves and how did they earn a living?

- Which scholarly professions utilised observational records (single reports, compiled diaries) for other types of predictive work?

Along the way it will become apparent why the title țup̌ar Enūma Anu Ellil is attested so rarely in the historical record.

1 The Neo-Assyrian period, ca. 709-627 BCE

The well-known corpus of celestial observation reports and associated letters from named scholars to Assyrian kings comprises well over 600 items." They were sent from a much smaller range of places than commonly assumed: not "all over the empire", as I have myself written, but only from the cities of the so-called "central triangle" of the Assyrian heartland —Arba'il, Assur, Ekallatu, Kasappa, Kilizi, Kurba’il, Kalhu, and Tarbișu; the far western outpost of Harran; and a cluster of northern Babylonian cities-Babylon, Borsippa, Dilbat,

11 Hunger (1992); Parpola (1993); Fincke (2010). 
and Kutha-along with Uruk and maybe Ur in the south. ${ }^{12}$ Conversely, the corpus is from a much wider time-range than commonly assumed. Although it clusters densely in the years 679-665 BCE, namely the reign of Esarhaddon and the first few years of his son Ashurbanipal, there are two reports dated explicitly in their colophons to the last decade of the eighth century BCE, plus a handful written in the 650s and early $405 .{ }^{13}$ However, no extant celestial divination report to an Assyrian king post-dates the civil war of 652-648 BCE. Meanwhile, from Babylonia a smattering of anonymous lunar observations from the 740 os to 630s BCE is preserved in a compilation from the late fourth century BCE or later (see further Section 2 below). A few "proto-Diary" observational compendia survive from this time as well. ${ }^{14}$ We can therefore examine the evidence from this period from three different perspectives: from the royal palaces at Nineveh; from the points of view of the Assyrian reporters; and from Babylonia.

Let us begin with the palace perspective. A well-known document found in one of the ruined Assyrian royal palaces at Nineveh names forty-five men, grouped into eight scholarly professions. It begins as follows: ${ }^{15}$

Issar-šumu-ereš, Nadin-ahhe, Balassu, Bunaya, Kișir-Nabu, Etel-pu, Bel-ețir: [total 7 țupšar] Enūma Anu Ellil.

The next entries are for 9 āšipu-healers, then ${ }_{5}$ bārû-diviners, 9 asû-healers, 6 kalu-lamenters, 3 dāgil iș̣ūrī bird augurs, 3 Egyptian harțibu-scholars, and 3 Egyptian scribes. The text is dated only to the month and day but, given the presence of the Egyptians, Karen Radner argues that it was probably drawn up shortly after Esarhaddon's military campaign to Egypt in 671 BCE. ${ }^{16}$

This text, it is commonly agreed, provides evidence that members of five native scholarly professions, and three "foreign" ones, were employed at the Assyrian court; that this "inner circle" of courtier-scholars was typically several dozen strong; and that the most

12 Fincke (2010: 49, 57) identifies Wiseman and Black (1996): no. 29 from Kalhu and Gadd and Kramer (1966): no. 413 from Ur as hitherto unrecognised celestial omen reports.

13 Hunger (1992: XX); Fincke (2010: 57).

14Steele (2000); and in this volume.

15Fales and Postgate (1992): no. 1, obv.i 1-8.

16 Radner (2009: 222). 
prestigious and influential of them were the țušarrū Enūma Anu Ellil, headed by Issaršumu-ereš—-whom we know from other evidence to have been Esarhaddon's ummânu or rab țupšarrī "chief scribe".

But the situation was more complex than that. Although the document itself tells us nothing of its purpose, it is reasonable to suppose, in parallel with similar records, that it lists all of the scholars present at court on one particular day. ${ }^{17}$ Only a dozen of these men, including Issar-šumu-ereš, Balassu, Bel-ețir, and Nadin-ahhe, are unambiguously identifiable elsewhere in the voluminous Assyrian royal correspondence of the period, perhaps a further four individuals if we accept they could hold different professional titles. ${ }^{18}$ The nine members of the three non-Babylonian professions at the end of the roster are never mentioned elsewhere. Some scholars may have come to Nineveh solely for a special event such as a feast or ceremony, while even those with the longest, closest relationship to the king were not employed by him as such, in the sense of a permanent, exclusive contract. As I have shown in detail elsewhere, the royal āšipus and kalûs were primarily priests, supported by regular income from temple endowments in Kalhu and Harran respectively, while individual āšipus and asûs also cared for other clients, who sometimes took priority over the royal family. ${ }^{19}$ The king rewarded good service with patronage gifts, such as clothing and land rights, which he could also take away, and punished bad service with galitu, "expulsion" — and possibly worse. $^{20}$

Beyond this one document, the title țupšar Enüma Anu Ellil is rarely found in the Assyrian state archives. Some royal correspondents referred to other men as țupšarrū Enūma Anu Ellil, but never in reference to specific practices. For instance, crown prince Šamaššumu-ukin wrote to his father Esarhaddon in 670 BCE to denounce three Babylonian scholars: one bārû-diviner and two țupšarrū Enūma Anu Ellil who "observe the skies all night and day" mūšu kalla ūmu šamê idaggul. ${ }^{2}$ According to informers from nearby Borsippa, these traitors had defected to Assyria's arch-enemy Elam. By contrast, the outcast Marduk-šapikzeri is careful to avoid the title in his famous letter offering to supply a retinue of "twenty

17 E.g. Fales and Postgate (1992): nos. 149-153.

18 Robson (forthcoming: chapter 4, 1-2).

19 Robson (forthcoming: chapter 4); also Gabbay (2014a; 2014b) on kalûs.

20 Parpola (1987); Westbrook (2005); Robson (2011a).

21 Luukko and Van Buylaere (2002): no. 21, obv.23 - rev.2. 
able scholars" if permitted to return to court. ${ }^{22}$ Instead, he and some of his apprentices a/iltasi "have read", a/ile"i "are able in", or ugdammir "have completed" the various scholarly disciplines, dullu and series, iškaru, including Enūma Anu Ellil. Only two men are identified explicitly as āšipus, another as an asû. None, despite their expertise in the requisite learning, is labelled as a țupšar Enūma Anu Ellil.

Likewise, and most importantly for the topic at hand, the very men who reported on celestial observations almost never self-identified as țup̌ar Enūma Anu Ellil either. With a single, late exception it was a professional designation that they simply did not use. Most of the time reporters and letter-writers identified themselves by given name only, on the expectation that the recipient - whether the king or one of his scribes-already knew their identity. Chief scribe Issar-šumu-ereš, the most senior scholar in the land, sometimes substituted his title, rab țupšarrī, for his name at the bottom of his Reports (but never in letters). ${ }^{23}$ Otherwise Assyrian correspondents who were external to the court might identify themselves, individually or collectively, by city (e.g., Nabu'a of Assur; the scribes of Kilizi). ${ }^{24}$ Two men referred to themselves as the rab ešerti of a city, literally "decurion" or "commanderof-ten (men)". ${ }^{25}$ This was a general-purpose term that was used in Neo-Assyrian hierarchical organisations such as army units and labour forces to denote a position below the more senior "cohort commander" rab kișri and "commander-of-fifty" rab hanšê. ${ }^{26}$ Babylonian scholars too sometimes identified themselves by city, and sometimes also by familial descent (mahrû or qatnu, "senior" or "junior"; son, nephew, or descendant of so-and-so). In addition, one man signed off reports with the scholarly title āšipu, another as kalû. ${ }^{27}$ Only an individual named Šumaya, author of two or three lunar reports in Babylonian script, once

22 Parpola (1993): no. 160. The translation is inconsistent and misleading, regularly eliding the distinction between ability in a scholarly discipline or series, and the possession of the relevant professional title. Similarly, throughout the book professional designations such as "astrologer" in chapter titles are merely a structuring device for grouping letters by content, and are not based on explicit ancient self-identifications. Caveat lector!

23 E.g. Hunger (1992): no. 2.

24 E.g. Hunger (1992): no. 126; Parpola (1993): no. 143).

25E.g. Parpola (1993): nos. 128, 138.

26 Postgate (2007: 344); Van Buylaere (2010: 235).

27E.g. Hunger (1992): nos. 456, 569. 
calls himself a țupšar Enūma Anu Ellil ša kișri eššu "of the new team". ${ }^{8}$ We should probably not read too much into Šumaya's use of kișru for his "team" or "cohort", as this word also had many informal uses outside institutional contexts.

Arguably, it would have been redundant for reporters to identify as a țup̌̌ar Enūma Anu Ellil in expert correspondence on celestial observation, and so we should perhaps not expect to find the title there. However, with varying degrees of confidence we can identify the titles used by some of the reporters in other contexts. Here too, they choose to represent themselves as members of other scholarly professions rather than as țušarrū Enūma Anu Ellil. The evidence, comprising information from colophons on scholarly works and passing references in royal correspondence, is clearest for the courtiers closest to the king. Urad-Ea, of the eminent Šumu-libši family, was concurrently chief kalû of the king and kalû of Sin's temple in the far western Assyrian provincial capital Harran; Uri Gabbay argues that he also held the post of chief kalû at Marduk's temple Esangila in Babylon. ${ }^{29}$ The well-known descendants of Gabbu-ilani-ereš, meanwhile, comprised a veritable dynasty of āšipus based at Nabu's temple Ezida in Kalhu. Members of that family who are also documented as reporters include brothers Nabu-zeru-lešir, Esarhaddon's rab țupšarrī, and Adad-šumu-uṣur, h is āšip šarri; and the former's sons Issar-šumu-ereš and Šumaya, who became Ashurbanipal's rab țupšarrī and āšipu respectively..$^{30}$ The family's scholarly tablets excavated from the scriptorium of the Kalhu Ezida include over two-dozen manuscripts of Enüma Anu Ellil and a draft Report on a lunar eclipse in Nisannu (month I). ${ }^{31}$ Last but not least, Akkullanu, as šangûu-priest of Aššur's temple in Assur, was one of the most senior clergymen in the land.$^{32}$ In other words, as far as the extant evidence takes us, in the $7^{\text {th }}$ century BCE the Assyrian kings' most trusted reporters were all primarily priests.

28 Hunger (1992): no. 499, rev. 4-6; also no. 498 and possibly also no. 450 (if Šum-iddin is the long form of the hypocoristic Šumaya). This man is certainly not the Šumaya son of Nabu-zerulešir who appears to have worked as an āšipu for crown prince Ashurbanipal in Tarbișu and who wrote half a dozen Reports in Neo-Assyrian script (Hunger 1992): nos. 175-180; Parpola (1993): nos. 257, 273, Luukko and Van Buylaere (2002): nos. 34-35.

29 Gabbay (2014a: 242-2; 2014b: 120).

30E.g. Robson (2014: 7-8).

31 Wiseman and Black (1996): nos. 1-26, 30, no. 29; Fincke (2010: 49-52); Robson et al. (2007-12) s.v. 'Kalhu'.

32 Villard (1998). 
The contemporary Babylonian evidence is much patchier and more circumstantial, but points in the same direction. ${ }^{33}$ We have already seen that two Babylonian reporters give their professions as āšipu and kalû respectively, while another named Rimutu might well be the Babylonian āšipu of the same name attested at Assurbanipal's court. ${ }^{34}$ A further four individuals are homonymous with men associated with Babylonian temples, although at this point the identity between them is purely speculative. Nadinu, Zakir, and Aplaya of Borsippa may have been prebendary priests of Nabu in Borsippa, while Šum-iddin (see note above) is the name of a šatammu-priest of Marduk's temple Esangila in Babylon..$^{35}$

2 The long sixth century, 626-485 BCE

As John Steele argues elsewhere in this volume, the Diaries were created as a standardised genre of regular record-keeping in the so-called "long sixth century' between the fall of the Assyrian empire in the 620s-61os BCE and the Persian repression of northern Babylonian temple communities in 484 BCE. However, in part due to the accidents of archaeological preservation, recovery and publication there is frustratingly little contemporary evidence for activity relating to Diaries, whether from the palace, the temple or the family archive. Just two Diaries survive from this period, plus a small but steady stream of eclipse observations, mostly preserved in much later manuscripts. ${ }^{36}$ Accordingly, we have to work a little harder than before to investigate the circumstances of the production and consumption of observational data, but there are useful hints to be found.

First, we simply do not know whether Babylonian kings consulted celestial omens at all, let alone whether they adopted, adapted or rejected Assyrian models of scholarship. Given how closely Babylonian imperial structures were modelled on Assyrian precursors, it is initially striking that scholars are missing from the apparently exhaustive list of governors,

33 A partially preserved Report found at Ur, dating to $657 \mathrm{BCE}$, suggests that not every set of Babylonian observations was made for the benefit of the Assyrian king (Gadd and Kramer 1966: no. 413; Fincke 2010: 57).

34 Radner and Baker (1998-2011), s.v. 'Rēmūtu' nos. 9-11.

35 Radner and Baker (1998-2011), s.v. 'Aplāia or Apil-Aia', nos. 17 and 19. 'Nādinu' no. 12; ‘Šumu-iddina' nos. 3 and 5; 'Zākiru' nos. 4 and 7. 
courtiers and high priests in Nebuchadnezzar's so-called Hofkalender. ${ }^{37}$ But there are several possible explanations for this omission: first, the text is badly damaged and the list incomplete; the king's scholarly entourage may have featured in a now missing section. ${ }^{8}$ Alternatively, scholars are absent from this list, which records grandees assigned to work on the construction of Nebuchadnezzar's palace, solely because they did not participate in this work; perhaps they contributed instead through ritual or cultic performance. Third, it is possible that the scholars' textual absence does in fact reflect their real-life absence from the Babylonian court. We have already seen that Assyrian royal patronage of scholarship declined early in the 64Os BCE and thus it may simply not have figured in the courtly model of governance that Babylon adopted a generation later. As ever, absence of evidence does not constitute evidence of absence.

The building inscriptions of the early Neo-Babylonian, or Chaldaean, kings hint at the use of bārûs and ǎšipus in the performance of temple construction, but it is not clear whether these personnel were supplied by the crown or by the priesthood. ${ }^{39}$ I have found no reference, however oblique, to celestial divination in determining auspicious times for Babylonian royal action before the inscriptions of the usurper Nabonidus (ruled $555^{-539}$ BCE). Even these are not straightforward. The best known example is Nabonidus' description of the moon setting in eclipse on the $13^{\text {th }}$ of Ululu (month VI) as a sign that "the moon-god Suen requests an entu-priestess"..$^{\circ 0}$ But, as Erica Reiner argued many years ago, this statement is part of an elaborate antiquarian construction designed to justify the new king's resurrection and promotion of a moribund cult. ${ }^{41}$ Given what we now know about the Chaldaean dynasty's closeness to Uruk and Eanna, we can also read the whole move as a strategy to disempower the old regime's southern power base and to set up a new rival. ${ }^{42} \mathrm{On}$ another occasion Nabonidus simply dreamed of a favourable alignment of heavenly bodies,

$36 A D-567,-566$; Hunger and Sachs (2001): nos. 3-8.

37 Da Riva (2013a; 2013b); Jursa (2010b; 2014).

38 Da Riva (2013a: 201).

39 E.g. NbplC31 ii 24-31 (Da Riva 2013b: 82-4).

40 En-Ningaldi-Nanna Cylinder I 8-10 (Schaudig 2001: 373-5).

41 Reiner (1985: 8-9).

42 Jursa (2007); Fuchs (2014). Kleber (2008: 12-17) details Nabonidus' reorganisation of Eanna's cult and administration at the beginning of his first regnal year, bringing it "unter die ausschließliche Kontrolle von königlichen Beamten". 
with his predecessor Nebuchadnezzar appearing in the same vision to explain their meaning. ${ }^{43}$ In this way he bypassed the living scholars' observations and interpretations entirely, while co-opting the authority of a former royal power to whom many members of the elite were still loyal. We should not take either of Nabonidus' accounts as an objective description of Neo-Babylonian court procedure for Reporting.

In terms of evidence for communication between kings and scholars, the Babylonian court does not offer us anything like the Assyrian royal correspondence to draw on because, as Michael Jursa argues, for the most part official communications were written in alphabetic Aramaic on long-perished organic media. ${ }^{44}$ Yet as Jursa also shows, Babylonian kings continued to write to major temple officials in cuneiform, on clay, and there is nothing in the admittedly scarce surviving letters and the slightly more plentiful replies to them to suggest that temples formally provided divinatory reporters or reports to the state. However, the extant epistolary evidence is all from the Eanna temple in Uruk and, to a lesser degree, the Ebabbar temple in Sippar, not Esangila in Babylon, where we suspect the Diaries were produced. ${ }^{45}$ Nonetheless, given Ebabbar's renown in bārûtu or sacrificial divination, one might expect hints of analogous services rendered to the court from Sippar, if they had been provided. ${ }^{6}$ There were certainly observers of some sort in Eanna, as attested by the evidence discussed below.

Whereas in Assyria the king endowed temples directly, which then paid for their priestly staff, Caroline Waerzeggers has shown that in the long sixth century Babylonian priesthood was an inherited, part-time privilege: a duty to serve the gods on certain days of the month or year, in exchange for rights to a share of the redistributed offerings. ${ }^{47}$ Waerzeggers identifies

43 Beaulieu (1989: 110-11); Babylon Stele VI 4-36 (Schaudig 2001: no. 3.3a, pp. 519, 525).

44 Jursa (2014).

45 Clancier (2009: 159-63, 169-72).

46 On the basis of five surviving letter-orders, Beaulieu (1989: 6-12; followed by Rochberg 2004: 224-5) argued that Nabonidus sent scholarly "experts", ummânu, from Babylon to Sippar's Ebabbar to excavate the temple's foundations and look for ancient inscriptions there. However, Bongenaar (1997: 367-9) used a large number of ration-list entries from Ebabbar to argue that these ummânu were in fact artisanal "experts", such as kutimmu-goldsmiths and kabšarrujewellers, who regularly travelled to Ebabbar in the late spring-perhaps in order to carry out delicate repairs to the gods' adornments-over a period of at least sixty years, ca. 585-525 BCE. 47 Waerzeggers (2011). 
four main categories of these prebendary priests: caterers, who sourced and prepared the gods' meals; artisans, who maintained the material fabric of the temple and its contents, including the statues of the gods themselves; bureaucrats, who ensured the smooth running of temple affairs; and of course the ritualists, who served the gods directly through performance of temple cult. All temples needed priests in each of these categories, but not every temple deployed the full range of professions. In smaller temples in particular, a single individual could hold more than one type of prebend simultaneously. Most, if not all, of the larger temples deployed āšipus and kalûs for certain cultic duties, but for the most part the prebendary status of these professions is unclear and in any case is unlikely to have been the same in every Babylonian city. ${ }^{48}$

This new understanding of Babylonian temple professions has important consequences for the riddle of the apparently invisible scholarly profession of țupšar Enüma Anu Ellil at this time, and the related question of who was observing and documenting the night skies. Two depositions made in the summer of 531 BCE to the senior officials of the Eanna temple in Uruk and its subsidiary Ebabbar in nearby Larsa provide important evidence here:49

[Four named men], the kalûs of the Lady-of-Uruk, stated [to the senior officials of the temple] as follows:

"On the 13th day of Simanu (month III), in the 8th year of Cyrus, king of Babylon, king of the lands, when we placed the copper kettledrum at the gate of Eanna, we did not consult with Nabu-mukin-apli, the šatammu of Eanna, son of Nadin, descendant of Dabibu, or with Nabu-aha-iddin, the courtier, commissioner ( $\check{s} a$ rês šarri bèl piqitti) of Eanna, about placing the kettledrum (there). And they did not approach us about it until it was time to remove the kettledrum."

Arad-Marduk, scribe, son of Marduk-šum-iddin, descendant of Bel-apal-ușur. Uruk, Du'uzu (month IV), day 18, year 8 of Cyrus, king of the lands.

[Three men] stated as follows [to the officials of Ebabbar]:

48 Robson (forthcoming: chapter 5).

49 Beaulieu and Britton (1994); translations mine. On Larsa's subsidiary relationship to Uruk see Beaulieu (1991; 1993). 
"On the 13th day of Simanu, in the 8th year of Cyrus, king of Babylon, king of the lands, after sunset the kalûs of Ebabbar placed a copper kettledrum at the gate of Ebabbar and declared, 'Eclipse!' And all the people of Larsa saw our placing of the copper kettledrum."

Arad-Marduk, scribe, son of Marduk-šum-iddin, descendant of Bel-apal-ușur. Uruk, Du'uzu (month IV), day 15, year 8 of Cyrus, king of the lands.

As Paul-Alain Beaulieu and John Britton convincingly showed, the kalûs of Uruk here take responsibility for a mistimed eclipse ritual, which was also performed in Larsa under their instruction. The date of their public performances coincides with the predicted date of a lunar eclipse according to a Babylonian astronomical model that had been developed some time before ca. $575 \mathrm{BCE}$, based on compilations of observational data from the mid-eighth century onwards. ${ }^{50}$ Now anachronistically called the Saros, it was known to its original users simply as 18 šanātu "18 Years" because it predicted that an eclipse of the same magnitude and direction should occur (if not be visible from Babylon) every 223 synodic months, or roughly 18 years plus 10 or 11 days. ${ }^{11}$ There were $3^{8}$ eclipse possibilities per 18-year Saros cycle, one every five or six months. According to this model, there was indeed a possibility of an eclipse on the night of 15 June (or 8 Simanu), 531 BCE but it would not have been visible in Babylonia. ${ }^{52}$ In other words, the Eanna kalûs knew how to predict eclipse possibilities using the Saros but misjudged the likelihood of the eclipse's visibility in this particular case. They must have had rules for assessing visibility, for in the previous 18-year cycle only 15 of the 38 eclipse possibilities had actually been visible to them, and it is difficult to imagine any temple expending resources and squandering prestige on ritual performances every five or six months for celestial events that failed to materialise more often than not. Indeed, the very fact that the kalûs were held accountable in this particular instance strongly suggests that normally their prediction methods worked.

For our purposes, it is significant that the men responsible, both for the performance and for the astronomical decision behind it, are identified in the depositions as kalûs: this, then, was their official relationship to the temple. Very little else is known about the three

50Steele (2000: 432); Brack-Bernsen and Steele (2005).

51 Steele (2000: 424. n 11).

52Steele (2000: 436). 
kalûs of Larsa. ${ }^{53}$ More can be said about their counterparts in Uruk. Contemporary legal documents show that chief kalû Šamaš-tabni-uṣur also held a prebend as țup̌ar Eanna "scribe of the Eanna temple", namely one of the senior administrators who supported the šatammu's work. ${ }^{54}$ Two of his three colleagues are attested elsewhere in the Eanna archive without titles. ${ }^{55}$ All belonged to the Sin-leqi-unninni or Iddin-Ellil families, other members of which are documented as prebendary kalûs and țušarrū Eanna respectively..$^{56}$ The scholarly title kalû was thus context-dependent, used only in pertinent circumstances. If any of the kalûs also held the title țup̌̌ar Enüma Anu Ellil, as one might expect, the scribe of these two documents, Arad-Marduk, did not feel that fact was germane to this deposition. We cannot tell if the kalûs were themselves observers of the night sky-except in the trivial sense that they must have noticed when the predicted lunar eclipse failed to happen-but they were certainly consumers of observed and predicted data, whose origins were presumably in Babylon.

3. The Late Achaemenid period, 484-331 BCE

The temple elites of Uruk and Babylon had had close ties with each other and with the Babylonian royal family for centuries: dynastic founder Nabopolassar's father had been governor of Uruk under the Assyrians and as crown prince Nebuchadnezzar had been Eanna's šatammu.$^{57}$ Men with northern Babylonian names, such as the scribe Arad-Marduk, served in Eanna alongside southerners such as Šamaš-tabni-uṣur. But those ties were eventually broken, first by the usurper Nabonidus in 555 BCE and then, irrevocably, by the Persian conquerors in 539. These new kings, who did not belong to the northern Babylonian temple communities, began to treat them more as exploitable financial resources than as sources of political support and divine legitimation. Long-running tensions over taxation, control and institutional independence erupted into anti-imperial revolts in $5^{20}$ BCE and

53 Beaulieu and Britton (1994: 74-5).

54 Kümmel (1979: 147); Hackl (2013: 289).

55 Kümmel (1979: 132 n171, 147).

56 Beaulieu (2000); Kümmel (1979: 125).

57 Jursa (2007); Fuchs (2014). 
again in 484 BCE, led by figures with ties to the former dynasty. The consequences of the reprisals, visible in the archaeological record as a widespread "end of archives", in Caroline Waerzeggers' phrase, were, as I have argued elsewhere, deep and devastating for cuneiform scholarship, as for many other aspects of Babylonian urban life..$^{8}$ However, those consequences were felt differently in different places, making a variable impact on diarists and their associates, just as they did on other individuals and communities.

If there had been any patronage of cuneiform scholarship in the early Achaemenid court, there was certainly none now. In Babylon itself, the ziggurat Etemenanki was decommissioned by removal of its staircase..$^{99}$ In Marduk's temple Esangila, as Johannes Hackl has shown, the senior posts of šatammu and qīpu were abolished and the system of prebendary priesthoods dismantled. ${ }^{60}$ In theory these measures disempowered and pauperised the local elite families who, by virtue of their inherited prebends and resultant wealth, had dominated local institutions and influenced state politics for centuries. That was certainly the short-term outcome: as Heather Baker has demonstrated, many houses in the wealthy district of Babylon now known as Merkes, from the Processional Way to the eastern city wall, were abandoned at this time, and the city quarter never regained its former prosperity. ${ }^{61}$

Gradually, however, the temple community regrouped and reorganised, focusing only on its own internal business since it had been excluded from state affairs. Esangila was now managed by a collective called "the scribes and commissioners of Esangila", țup̌arrū u bēl piqnēti ša Esangila, comprising representatives from each of its constituent professional groups. ${ }^{62}$ Each of these in turn-including āšipus, kalûs, and, separately, țupšarrū Enūma Anu Ellil—was governed by a guild-like kiništu, "collegium" or "assembly", chosen (in ways that are not yet clear) by and from its own members. ${ }^{63}$ An annual payment record for Esangila's țup̌arrū Enūma Anu Ellil sometime in the fourth century BCE-anywhere between 85 and 170 years after the "end of archives"—shows 14 of these men, each receiving

58 Waerzeggers (2003/04); Robson (2017; 2018).

59 George (2010).

60 Hackl (2013: 293-5).

61 Baker (2008).

62 Hackl (2013: 297-9).

63 Hackl (2013: 299-300). 
a monthly kurummatu-ration of 1 kurru, ca. 150 litres, of barley (which could then be traded for other goods): ${ }^{4}$

Barley for the kurummatu-rations of the țušarrū Enūma Anu Ellil, from Nisannu (month I) until the end of Addaru (month XII) of the 6th year, in the care of Ahhe-.... 1 kurru: Ea-iddin, son of Šumaya

1 kurru: Ea-aplu-iddin, son of Ea-iddin

1 kurru: Libluț, son of Marduk-šumu-lī̌sir

1 kurru: Balāṭu, son of Marduk-šumu-līšir

1 kurru: Bēl-apla-iddin, son of Bēl-bullissu

1 kurru: Bēl-uballiț, son of Bēl-ahhe-iddin

1 kurru: Bēl-bullissu, son of Arabi

1 kurru: Ea-bullissu, son of Ea-lūmur

1 kurru: Nergal-tēši-ēṭir, son of Iddiya

(several lines missing)

14 kurru of barley: kurummatu-rations of Arahsamnu (month VIII), year 6

14 kurru of barley: kurummatu-rations of Kislīmu (month IX), year 6

14 kurru of barley: kurummatu-rations of Țebētu (month X), year 6

14 kurru of barley: kurummatu-rations of Šabațu (month XI), year 6

14 kurru of barley:kurummatu-rations of Addaru (month XII), year 6.

None of the men is given a family name, but amongst them are a father-son pair and two brothers. The rest are apparently unrelated to each other. The document does not specify what they did to earn their keep, whether their duties were part-time or full-time, or whether they all performed the same tasks or specialised within the group. However, it is reasonable to suppose that the diarists were amongst their number: from the decades immediately after the Babylonian revolts a few eclipse observations and Diary entries survive—not many, but enough to show that at least some observers and reporters continued their work. Amongst them were one [Bel?]-uṣuršu, son of Nabu-uballissu, whose name appears on the colophon

64 YBC 11549 (Beaulieu 2006). As Beaulieu (2006: 7-8) points out, the sixth regnal year of an unnamed king translates to possible dates of 399/8 (Artaxerxes II), 353/ 2 (Artaxerxes III), 318/ 7 (Philip III), 312/11 (Antigonos), or 311/1o (Alexander IV). 
of $A D-372 \mathrm{~A}$ (Artaxerxes II 32 ); and Uballissu-Bel, son of Bel-apla-[iddin], scribe of $A D-361$ (Artaxerxes II 43). Unfortunately, as Beaulieu notes, it is currently impossible to identify either of these names in the contemporary archival record of Esangila. ${ }^{65}$

What of the professional consumers of the diarists' data? Now that cuneiform scholarship could no longer count on royal patronage, scholarly communities had to intensify their focus on private clientele in order to survive. We have two good sets of evidence for how this worked out in practice, from the southern cities of Nippur and Uruk.

In Uruk, as I have argued elsewhere, the goddess Ištar's temple Eanna was already in direct confrontation with the Persian crown in 520 BCE, and seems to have been decommissioned even before the revolts against Xerxes in 484 BCE. ${ }^{66}$ At that point, as Karlheinz Kessler has shown, the northern Babylonian families of Uruk-presumably those with long-standing ties to the former Neo-Babylonian dynasty-vanish from the historical record ${ }^{67}$ Over the course of the fifth century BCE the surviving southern elites in Uruk slowly regrouped around the god Anu's temple Reš. Claus Ambos has recently argued that this building had existed in physical form since at least the early seventh century BCE but the community conceptualised its origins much deeper in the ancient past. ${ }^{68}$

In the later fifth century BCE, the legal documents and scholarly tablets of the ŠanguNinurta family of āšipus show no signs of institutional affiliation, although their forebears had been closely associated with Eanna. ${ }^{69}$ About 160 scholarly tablets can be assigned to these men, whether by names in colophons or through archaeological stratigraphy of the family house in which they were found. The majority are clearly related to the healing profession: therapeutic recipes and instructions, incantations and rituals, omens and omen commentaries. However, at least three record compilations of long-ago Diary-like observations of lunar eclipses and/or planetary positions, spanning the reigns of Nebuchadnezzar II to Artaxerxes I (ca. 604-461 BCE). ${ }^{\circ 0}$ As John Steele has argued, these

65 Beaulieu (2006: 19); and see note 2 above. Oelsner (2000: 804-5) speculates that the two men might have been members of the Mušezib family, discussed further in Section 4 below.

66 Robson (2017: 465).

67 Kessler (2004).

68 Ambos (forthcoming).

69 Robson (2017: 468); for their tablets see conveniently Robson et al. 2007-12 sv. Ǎšipus' house.

70 Securely attributable on stratigraphic grounds: Hunger (1976): no. 100; von Weiher (1998): nos. 266, 268; unstratified but similar in style and content: von Weiher (1993) nos. 169, 171; 
observations were most likely made in Babylon; more speculatively, we could posit that all but the latest had arrived in Uruk via the Eanna temple, with which the Šangu-Ninurta family had formerly been associated, when the connections to northern Babylonian temple culture were still strong. The family also owned instructions for identifying the cause of an eclipse, and maybe a monthly calendar of the constellations that rise at sunset at midmonth. ${ }^{71}$ But what they did with this material, and how, if at all, it related to their work as $\bar{a}$ šipus, it is currently impossible to say.

Meanwhile, the city of Nippur, roughly equidistant between Babylon and Uruk but relatively cut off from the political mainstream, ${ }^{72}$ had not taken part in the revolts against Darius and Xerxes and was not, therefore, a victim of royal reprisals. The city's institutions and elites remained intact, centred on the temples of Ellil, Ninurta and their dependent sanctuaries, just as they had been for centuries. ${ }^{73}$ The long-standing prebendary system continued to provide income and status for men such as the descendants of Absummu (a Sumerian name), studied by Francis Joannès in the early 1990s. ${ }^{74}$ Joannès identified over sixty tablets relating to two generations of this family, in museum collections acquired by purchase from the antiquities market in the early $20^{\text {th }}$ century. ${ }^{75}$ This reconstructed archive documents the activities of one (Ellil-)Belšunu, son of (Ninurta-)Nașir, and his sons Ninurtaahhe-bulliț and Zer-kitti-lešir over a fifty-year period, ca. 414-364 BCE. Some forty letters, legal documents and administrative records show the father, and especially the first son, managing the temple's flocks and receiving dates and silver for the performance of their brewing duties. Here they are known only by their given names and patronyms. Almost thirty scholarly and medical tablets can also be associated with the same family, via close physical similarity, adjacency in museum collections, and names on colophons. Most are ad hoc therapeutic recipes, incantations, and ingredient lists written on small tablets, along

(1998): no. 267 (Steele 2016: 93).

71 Hunger (1976) nos. 95 (constellation calendar) and 97 (fragment); von Weiher (1993) no. 161 (eclipse instructions).

72 Jursa (2010a: 405).

73 Beaulieu (1995).

74 Joannès (1992).

75 See http://oracc.org/cams/absumu for a convenient online edition of these tablets. 
with one of Babylonia's oldest extant birth horoscopes, dated 410 BCE.$^{7}$ More formally copied works, on larger tablets, include Diary-like planetary observations for $363-362$ BCE, a hymn to Ninurta, lexical lists, and scholarly commentaries. Both generations of the family were thus consumers of Diary-like data.

The men's scholarly titles are particularly revealing. In an undated colophon of a standard commentary to the therapeutic omen series Sakikkû "Symptoms", Ellil-belšunu identifies himself as "[junior?] āšipu-healer, son of Nașir, prebendary brewer (sīrāšû) of Ellil, descendant of Absummu the Sumerian". ${ }^{77}$ In 365 BCE his son Zer-kitti-lešir signed a copied list of Nippur deities receiving offerings in merdētu-ceremonies as, "son of Belšunu, junior scribe, descendant of Absummu the Sumerian". ${ }^{78}$ Two decades earlier, in $384 \mathrm{BCE}$, an administrative document records Zer-kitti-lešir as one of six țupšarrū ša Ekur, "scribes of the Ekur temple'" receiving barley from the temple storehouse. ${ }^{79}$ Like their counterparts in Uruk's Eanna, the țupšarrū ša Ekur were senior officials directly supporting the work of the top-level temple administration, far more than merely amanuenses and secretaries. In short then, this glimpse into a family archive reveals men with prebendary ties to the temple, though brewing and bureaucracy. When engaged in scholarly activity, including novel client services such as horoscope-casting, they could also take professional titles such as āšipu and țupšarru, but they did not use these terms when on temple business, whether because they were irrelevant or inappropriate. Either way, this adds further support to the argument first made above, in relation to Uruk's Eanna temple, that scholarly titles were not used in every circumstance. It is likely that in many times and places most scholars also had other roles and responsibilities, in the performance of which they put their scholarly titles aside. It also suggests that consumers of Diary-like materials came from all walks of scholarly life, especially as zodiacal concepts became ever more integrated into personal healing in the later first millennium BCE.

76 List in Joannès (1992: 97-100); also Foster (2005: 707-8); Hunger and Sachs (2001): no. 63; Maul (1994: 374-7); Rochberg (1998): no. 1.

77 AO 17661 rev.24-25 (George 1991: 152).

78 AO 17662 rev.13-14 (Nougayrol 1947: 38).

79FLP 1480 (Stolper 1988: 150); see Jursa (2005) on the identity of these two figures. 
4 The Hellenistic and early Parthian period, 330-ca. 5o BCE

Although Alexander's biographers suggest that the Macedonian king was intrigued by his encounters with local scholarship during his Babylonian sojourns of $33^{1}$ and 323 BCE, those same writers hint that other members of his entourage felt disdain (and threat?) at such interactions.$^{80}$ In any case, by the beginning of the third century BCE Alexander's erstwhile general Seleucus I Nicator had founded a new regional capital at nearby Seleucia-on-theTigris and was consolidating his eponymous new dynasty around Antioch-on-the-Orontes, almost $1000 \mathrm{~km}$ to the northeast of Babylon. His son and successor Antiochus I Soter attempted to keep Babylonia in the political mainstream, but in the long term the region was consigned to relative political obscurity. ${ }^{81}$ While the Seleucid state remained closely involved in city administration, royal engagement with traditional religious and cultural life was limited to the occasional pageant of a sacrifice at the gates of Esangila and sporadic participation in the akitu-festival at new year. In the absence of close supervision the temples gained a great deal of local autonomy and power at the expense of influence at imperial level, at least until institutions of Greek origin came to dominate political life in Babylon and perhaps Urukin the period $180-160$ BCE. ${ }^{82}$

Darius III had already restored the post of šatammu as head of Marduk's Esangila temple in ca. 36o BCE, while the guild-like kiništus continued to manage the priesthoods' collective interests. ${ }^{83}$ Alexander's promise to fund the restoration of the ziggurat destroyed by Xerxes was never fully realised, however, and nor did Antiochus I make good on his intentions to renovate the temple itself. ${ }^{84}$ Clancier and Monerie suggest that the functioning parts of Esangila were now reduced to the southern area known as the Juniper Garden. This was likely the site of extensive informal digs in the late $19^{\text {th }}$ century that yielded many of the thousands of cuneiform tablets, now mostly in the British Museum, that document the final centuries of the temple's activities. ${ }^{85}$

80 Van der Spek (2003).

81 Boiy (2004: 137); Pirngruber (2017: 38).

82 Sciandra (2012); Clancier and Monerie (2014); Clancier (2017).

83 Hackl (2013: 295).

84 George (2010); Clancier and Monerie (2014: 195-6, n. 48). 
As is well known, this corpus is dominated by the overwhelming bulk of the Diary manuscripts, plus many other genres that are generally assumed to be the work of tupšarrū Enūma Anu Ellil, in observational, predictive and mathematical astronomy. ${ }^{86}$ The complex calculations of the latter discipline, used to predict the positions of the moon, sun, and five visible planets, were developed in the late fourth and early third centuries BCE, apparently in Babylon. ${ }^{87}$ Although the origins of these methods are still far from clear, it is reasonable to suppose that they were inspired, at least in part, by the analysis of periodicities in observational Diary data. Very few manuscripts are attributable to individual scribes, however, as the scholars of Hellenistic Babylon did not routinely append colophons to their work. Several generations of the Mušezib family comprise a notable exception. ${ }^{88}$ For instance, $A D-321$ is annotated: "From(?) [...] Bel-apla-iddin, son of Mušallim-Bel, descendant of Mušezib, which he wrote for his good health, which was copied from the property of [...]." But, as Joachim Oelsner has already noted, this colophon tells us only that Bel-apla-iddin copied the manuscript from someone else, sometime after Philip II Arrhidaeus' second regnal year; it says nothing at all about the identity of the diarist himself. ${ }^{89} \mathrm{~A}$ man of this same name, Bel-apla-iddin son of Mušallim-Bel, descendant of Mušezib, also appears as owner of two tablets of mathematical astronomy, containing instructions for calculating the positions of Venus and Mercury respectively..$^{90}$ Again, as previous editors have noticed, in both cases there are clear indications that these are copies, not original compositions: one passage of the former is marked as hepi ě̌šu, "newly broken", while the latter is described as a gitttu-tablet, a format often associated with the final phases of scribal training in this late

85 Clancier and Monerie (2014: 196-7, n. 49). Unfortunately, as the crude methods of extraction used rendered the area unworkable for later archaeological exploration, it is highly unlikely that it will ever be possible to confirm this hypothesis beyond doubt. As Steele (2016: 84-5) notes, however, documented findspots from formal excavations in Babylon include other temples and residential buildings.

86 Boiy (2004: 27-36); Brown (2008).

87Steele (2016: 104-9).

88 Oelsner (2000: 802-11); Robson (2008: 221-5).

89 See previous footnote. Oelsner (2000: 804-5) and I (Robson 2008: 223 no. 4) both assume that $A D$-324A ("From [...]-Bel, son of Mušallim-Bel [...]") was also copied by a member of the Mušezib family, on the basis of the shared patronym, but this intuition is far from conclusive. 90 Ossendrijver (2012): nos. 5, 9. 
period. ${ }^{91}$ So, even if Bel-apla-iddin was not (yet) himself a diarist, he was apparently learning how to record celestial observations and perform predictive calculations. And, if Oelsner's reconstruction of the Mušezib family tree is correct, he was followed in these interests by his son Marduk-šapik-zeri, who in turn taught his own son Iddin-Bel..$^{92}$ But we do not know how any of these men self-identified as scholars or priests, as they recorded no professional title of any kind. Iddin-Bel once invokes Bel and Beltiya, "My lord and lady", i.e., Marduk and his spouse Zarpanitu, while his own apprentice, Nergal-ina-teše-ețir, calls upon [Nabu] and his spouse Tašmetu in a colophon to Enüma Anu Ellil Tablet $24 \cdot{ }^{93}$ I have argued elsewhere that these are expressions of personal devotion, closely allied to scholarly apprenticeship, rather than signifiers of formal temple affiliation..$^{94}$

Meanwhile in Uruk, the Reš temple had established a fully functional prebendary system by the late fourth century and continued to operate on the traditional model, excepting the absence of royal patronage and benefaction, well into the second century BCE. Scholarly activity appears to have petered out in the 16os BCE, at more or less the same time as Uruk was refounded as a Greek polis if Clancier and Monerie's hypothesis is correct. ${ }^{95}$ In the house formerly occupied by the late Achaemenid Šangu-Ninurta family, the descendants of Ekur-zakir now practised āšipūtu in their stead. The best attested family member, Iqišaya son of Ištar-šum-ereš, was an avid Consumer of celestial observation data in the 320s BCE, incorporating zodiacal elements into his healing practice in multiple ways. ${ }^{6}{ }^{6}$ Unsigned copies of planetary observations, originally made in Babylon, which were found in the same

91 See conveniently Stevens (2013: 220, n. 52).

92 Oelsner's chronology is not entirely convincing. One of Iddin-Bel's astronomical tables is concluded by the statement annâ(?) ša šanat 5 Pilipsu, 'this(?) is for the $5^{\text {th }}$ year of Philip (II Arrhidaeus)', namely $319 \mathrm{BCE}$, just a few years later than his putative grandfather's date in $A D$ -321 (Neugebauer and Sachs 1968-69: 94). But this does not establish the date of the tablet itself; it could as easily have been a copy of an older original as a fresh manuscript predicting celestial events that were yet to occur.

93 Most conveniently, Robson (2008: 224).

94 Robson (forthcoming: chapter 5).

95Clancier and Monerie (2014: 220-3).

96 Hunger (1976): nos. 94, 96; von Weiher (1982): no. 42; (1988): nos. 104, 105 and perhaps also von Weiher (1982): no. 49, (1993): no. 167 on stratigraphic grounds. See further Robson (2011b: $568)$. 
archaeological stratum of the house, may well have belonged to him too. ${ }^{97}$ The ŠanguNinurta family seem to have been engaged in a less diverse range of temple affairs than the Absummus of Nippur, but Iqišaya called himself "an āšipu of Uruk, a temple-enterer of Anu and Antu", thus clearly distinguishing between his civic scholarly calling and his prebendary duties at Reš. ${ }^{8}$

Within a century, however, Iqišaya's scholarly profession had been incorporated into the prebendary system of Reš alongside kalûtu. ${ }^{99}$ As is well known, Iqišaya's descendants in the Ekur-zakir family dominated the profession of āšipūtu in Hellenistic Uruk, while the descendants of Sin-leqi-unninni consolidated their Achaemenid hold on kalûtu (Section 2 above). About 300 of these men's scholarly tablets are known. Only about a third have secure archaeological provenance, but there is good reason to believe they had all been archived in the Reš temple. ${ }^{100}$ Some were discovered in clandestine digs in the early $20^{\text {th }}$ century; the remainder were excavated from previously looted rooms in 1959-6o. Almost half are astrological or astronomical in content; a third have surviving colophons recording crucial information about their owners, scribes and circumstances of production.

As I have shown elsewhere, in the period ca. 220-180 BCE three men of the Sin-leqiunninni family and three descendants of Ekur-zakir used the self-designation țup̌̌ar Enūma Anu Ellil. But they began to use it only after a period of training in mathematical astronomy with another, older man who had himself earned that title. ${ }^{101}$ For instance, Šamaš-ețir of the Ekur-zakir family - āšipu of Anu and Antu, chief priest of the Reš temple, țupšar Enūma Anu Ellil - trained Anu-aba-uter Sin-leqi-unninni, kalû of Anu and Antu. Anu-aba-uter in turn adopted the title țupšar Enüma Anu Ellil, and subsequently trained Anu-uballiț, another descendant of Ekur-zakir, who may have been Šamaš-ețir's nephew. The title țupšar Enūma Anu Ellil was not restricted to use in astronomical contexts, however: Anu-aha-ušabši of the

97 Von Weiher (1993): no. 170; (1998): nos. 269, 270, and 271; perhaps also von Weiher (1993): no. 168: although found in a lower stratum, the observations it records postdate the Šangu-Ninurta family's tablets by several decades. See also Steele (2016: 93).

98 Hunger (1976): no. 94; see also von Weiher (1982): no. 28, in which another Ištar-šumu-ereš (not Iqišaya's father) is named as a "kalu of Anu and Antu".

99 Corò (2005).

100 Robson et al. (2007-12) s.v. 'Uruk Illicitly excavated'; 'Uruk Resh temple library'; Robson (2017: 466).

101 Robson $(2007 ; 2008:$ 258-60). 
Ekur-zakir family, for example, who preceded his relative Šamaš-ețir in the post of chief priest, used it when copying sacrificial omens, vocabulary lists and-rather fittingly-a catalogue of Enüma Anu Ellil itself, but not on his only two surviving astronomical manuscripts. ${ }^{102}$ Yet none of these țup̌arrū Enūma Anu Ellil, nor any of their Uruk contemporaries, were diarists, although they did occasionally copy Diaries and Diary-like data from Babylon. ${ }^{103}$

As Lucinda Dirven and Johannes Haubold both describe elsewhere in this volume, the Parthian conquest of Babylon in 141 BCE led to a tumultuous two decades of rival occupations of the city, as the Seleucids sought to wrest back control from multiple competing regional powers. It was only in the late 120 s that Mithradates managed to assert full control over Babylonia. Yet the scholarly community of Babylon continued to function throughout this difficult transition — indeed, the Diaries are arguably the most vivid eyewitness accounts of the period - and into the mid-first century BCE. And although all of the Parthian Diary manuscripts are anonymous, we can situate them in relation to a few hundred more contemporary scholarly texts, including about 40 with colophons, and a reconstructed archive that, as currently known, comprises around fifty legal documents, letters and administrative records. ${ }^{104} \mathrm{~A}$ few of these documents have been discussed repeatedly over the past few decades but they have not, to my knowledge, been fully contextualised.

One of the best-known documents concerning celestial observation in Parthian Babylon is a memorandum recording a decision of the kiništu of Esangila to transfer the duties and rewards of an absent țup̌̌ar Enūma Anu Ellil to his two sons in 126 BCE:105

102 With the title țupšar Enūma Anu Ellil: Thureau-Dangin (1922): nos. 2, 4, 7, 15, 35; Robson et al. (2007-12) s.v. 'TCL' 6; without: Clay (1923): no. 13; Neugebauer (1955): nos. 174, 300; Thureau-Dangin (1922): no. 3.

103Steele (2016: 93, 95-100).

104 See http:/ / oracc.org/cams/parbab for an evolving catalogue and edition of the texts on which I have based this analysis. Hackl (2017) gives an up-to-date discussion of the closely associated Rahim-Esu archive.

105 BOR 4132 (Pinches 1896) is no apparently no longer extant. The best previous treatment is still van der Spek (1985: 459-51).My preliminary edition, on which this translation is based, is at http:/ / oracc.org/cams/parbab/X800003/. 
Bel-mahar, šatammu of Esangila, the Babylonians, (and) the kiništu of Esangila conferred with one another and said:

"Itti-Marduk-balațu, temple gardener, city supervisor(?), overseer of the gods' temples, țupšar Enūma Anu Ellil, son of Iddin-Bel, who had previously attended Hyspaosines the king, [...] from the supplies at the king's gate and is still there.

Bel-ahhe-uṣur and Nabu-mušetiq-udi, his sons, [...] are capable of making all the celestial observations. In regard to this, he (sic) has made a claim in front of this Belmahar and the Babylonians, the kiništu of Esangila, that from this day, every year, we should give 2 minas of silver, that were the kurummatu-rations of Itti-Marduk-balațu, their father, to Bel-ahhe-uṣur and Nabu-mušetiq-udi from our supplies.

In exchange, (they will do) everything that Itti-Marduk-balațu, their father, offered. They will make celestial observations and they will give ephemerides tables for every year, along with Belšunu, Labaši, Muranu, Iddin-Bel, Bel-uṣuršu, the țupšarrū Enūma Anu Ellil, and (any) other țupšarrū Enūma Anu Ellil.

As others have previously discussed, this memo demonstrates that the temple collective required their țupšarrū Enūma Anu Ellil both to make Diary-like observations (nașār nașāri) and to calculate astronomical tables (têrsêtu). ${ }^{106}$ Roles were inherited in the family, but only on practical demonstration of competence, and the holders earned a fixed annual kurummatu-ration rather than the prebendary rights of pre-Xerxian times. The țupsarrū Enūma Anu Ellil functioned as a team of about half a dozen, presumably working shifts to ensure that there was always someone on watch. What has been less remarked upon is that the absent Itti-Marduk-balațu was serving at the court of Hyspaosines, king of the marshland kingdom of Characene and briefly also ruler of Babylon. ${ }^{107}$ Sadly the document does not tell us whether the king had summoned him, the temple had sent him, or he had gone on his own initiative, speculatively seeking patronage. Nor can we infer whether many or all late

106 Still the most useful discussions of the technical terminology are by Rochberg (2000: 370371; 2004: 234-236); cf. footnote 9 above.

107 Clancier (2007: 34-5) gives an optimistically maximalist interpretation of this document, as evidence that the Neo-Assyrian court culture of scholarship in which "tous les érudits intervenant dans la protection spirituelle du monarque" is "encore attestée" in the Parthian period. Stolper's $(2007: 231-232,245)$ interest, by contrast, is in the meaning of the Old Persian title uppudètu, here translated "overseer". 
second-century claimants to the Babylonian throne, Seleucids, Parthians, or Elamites, counted a țupšar Enūma Anu Ellil amongst their entourage, or whether Hyspaosines was cultivating a distinctively traditionalist image in order to gain favour amongst the cuneiformliterate intelligentsia.

In a very similar document, written about a decade later, the son of a deceased țup̌ar Enūma Anu Ellil ousts a temporary replacement by performing in front of the kiništu, again demonstrating that family ties trump experience. ${ }^{108}$ The team that the young Beluṣuršu joined still included Labaši and Muranu, "sons of Bel-bullissu", we learn, who had been joined in the meantime by their brother Marduk-šapik-zeri; as well as the two earlier claimants, Bel-ahhe-uṣur and Nabu-mušetiq-udi, "sons of Itti-Marduk-balațu". ${ }^{109}$ Belšunu, Iddin-Bel and (a different) Bel-ușuršu had moved on or died; hence the need, in both cases, to foresee the possibility of newcomers working with "(any) other țupšarrū Enūma Anu Ellil" and not just the current incumbents of the post.

At roughly the same time, in 115 BCE, Muranu wrote to Bel-ahhe-ușur, using both men's patronyms, about uncollected kurummatu-rations, sealing the letter with the šatammu's seal to show that it concerned official temple business. ${ }^{100}$ Here Muranu describes himself as țup̌̌ar Enūma Anu Ellil, but instead acknowledges Bel-ahhe-ușur as prostatēsofficial of the previous year, strongly implying that this latter office carried greater weight. Recall too that in the first document quoted above, Itti-Marduk-balațu is given three different cultic and civic titles before being named as țup̌̌ar Enüma Anu Ellil. Similarly, the ousted scholar in the second document is described as a kalû-priest first, țupšar Enūma Anu Ellil second. As in Seleucid Uruk, then, this was a secondary role, a title invoked only in relation to the performance of its duties and (as in Muranu's letter) distribution of its rewards. We should not expect to find it used in other contexts.

108 Kennedy (1968): no. 144 (van der Spek 1985: 551-2; Rochberg 2000: 373-5; 2004: 234-5); http://oracc.org/cams/parbab/P481975/. On the šatammu's seal, see most recently Wallenfels (2017).

109 Marduk-šapik-zeri's successful bid to join his brothers is documented in the fragmentary Kennedy (1968): no. 185 (van der Spek 1985: 552-3); http://oracc.org/cams/parbab/P482017/, where we learn that Belšunu was also one of their brothers.

110 АB 247 (McEwan 1981: 139; van der Spek 1985: 553-4); http: / / oracc.org/cams/parbab/X800007/. 
These dozen or so men, then, from just three family groups, were almost certainly the very same individuals who wrote the dozens of extant, anonymous Diaries from the late second century BCE. ${ }^{\text {m }}$ But we can also situate them in a wider socio-intellectual context thanks to the colophons on two contemporary astronomical tables. As van der Spek already noticed thirty years ago, a Marduk-šapik-zeri, țupšar Enūma Anu Ellil, son of Bel-bullissu is mentioned as the source of two tablets copied by men of the Egibatila family, one of which is dated precisely to 103 BCE. ${ }^{112}$ At this same time, and up to a decade later, a small handful of Egibatila men were also copying literary works, commentaries on omens, and bilingual liturgical laments, often in close collaboration with the descendants of Nanna-utu. ${ }^{113}$ The Nanna-utu men in turn focused heavily on liturgy, along with a little mathematical astronomy. Two members of this family describe themselves as "junior kalû-priest of Marduk", one in the mid-13os BCE and the other in the mid-8os BCE. ${ }^{114}$ We have already seen a kalû brought in—and ousted again—to replace Bel-ab-uṣur as țupšar Enūma Anu Ellil; might he too have been a descendant of Nannu-utu? ${ }^{115}$ As others have noted, members of the Mušezib family also wrote mathematical astronomy and literature at around this time. ${ }^{16}$ Although they cannot as yet be linked unequivocally into this scholarly network, they cannot have been complete strangers to it either, given their common interests. For, as Lucinda Dirven has shown, in Parthian Babylonia the cultic traditionalists were a dwindling minority in an increasingly pluralistic society. ${ }^{117}$ It is hard to imagine that this community of highly literate cuneiformists, dedicated to the cult of Marduk, ever comprised more than a handful

111 For the family trees, see van der Spek (1985: 549).

112 Van der Spek (1985: 549). Neugebauer (1955): nos. 122 (Zo), 420+821b (Zld); Ossendrijver (2012: 294).

113See note 102 above and Robson (2018) with further bibliography.

114 Marduk-zera-ibni son of Ea-balassu-iqbi: Reisner (1896): no. 5 (137 BCE), Spar and Lambert (2005): no. 2 (134 BCE); (a different) Ea-balassu-iqbi son of Bel-apla-iddina: Reisner (1896): nos. $27,28,36$, and 55 (87-86 BCE); all balaggu-laments.

115 Van der Spek (1985: 549) suggests instead that he was of the Mušezib family, as were IttiMarduk-balațu and sons. However, given the number of personal names common to all three of the Egibatila, Mušezib, and Nanna-utu lineages, I prefer to reserve judgement here.

116E.g. van der Spek (1985): 458; Oelsner (2000).

117 Dirven (2014). 
of Parthian Babylon's estimated 20,000 inhabitants. ${ }^{118}$ And, by the mid-first century BCE, just a decade after the latest known Diary, it had vanished entirely.

6 Conclusions

The investigations undertaken here have largely confirmed some historians' earlier intuitions about the diarists but have also added local nuance, and social change, to the picture. ${ }^{19}$ The key long-term continuity lies in the fact that expert celestial reporters were predominantly associated with large urban temples, either as holders of part-time prebendary priesthoods or, in post-Xerxian Babylon, as recipients of kurummatu-rations. ${ }^{120}$ If these temple affiliations did not occupy much of their working lives, then supplementary Reporting duties took up even less. Many of the individuals we have looked at took on many concurrent, contextdependent professional identities. We have also seen that there was no simple relationship between textual mastery, practical competences, and use of the title țuš̃ar Enūma Anu Ellil. Let us summarise the findings.

In the seventh century BCE, almost none of the Assyrian king's reporters used the title themselves, even though they quoted the omen series Enüma Anu Ellil in every report they wrote; certainly, familiarity with the series' contents was not sufficient for others to label one as such as scholar. In the Babylonian long sixth century, when the Diaries established themselves as a stable textual genre, both reporters and țušarrū Enūma Anu Ellil are frustratingly absent from the historical record. We can, however, infer their influence at the Neo-Babylonian court from the lengths to which the usurper king Nabonidus went to undermine their authority. Shortly after, at the Eanna temple in Uruk, we see prebendary kalû-priests taking responsibility for the (mis)prediction of celestial events. It is only in the fourth century BCE that the țušarrū Enūma Anu Ellilare first explicitly attested as kurummatu-recipients at Esangila, Marduk's temple in Babylon, but we have no indication of their practical duties. In the late fourth century, members of the Mušezib family first appear

118 On the likely population of Parthian Babylon see Hauser (1999: 228).

119E.g. van der Spek (1985; 2008: 284-7); Rochberg (2004); Beaulieu (2000; 2006).

120 Contra Slotsky's assertion that "it may be excessive to speak of any of these astronomerscribes as priests" (Slotsky 1998: 103). 
in the colophons of Diaries and, a little later again, as users and producers of mathematical astronomy and other scholarly genres, but we do not know what, if any, scholarly or priestly titles they took. A century afterwards, in Seleucid Uruk, a few prebendary āšipus and kalûs of the Reš temple, descendants of Ekur-zakir and Sin-leqe-unninni respectively, took the secondary title of țup̌ar Enūma Anu Ellil after textual apprenticeship with a master of mathematical astronomy; but they did not undertake Diary-like activities. Finally, in late second century Babylon, members of three unidentified families collectively took responsibility for Recording and celestial prediction, as kurummatu-recipients of Esangila. The team of țup̌arrū Enūma Anu Ellil was now half the size that it had been in the fourth century BCE, but probably still included descendants of Mušezib as well as, perhaps, Egibatila and Nanna-utu. It appears that the young men undertook a similar textual training to their Uruk counterparts of the third century BCE, but they also had to demonstrate practical competence before their peers. Links to known copyists of Diary manuscripts are, once again, suggestive but not conclusive.

In short, the circumstantial evidence that identifies the diarists as țup̌rarrū Enūma Anu Ellil of Marduk's temple in Babylon becomes more persuasive as (ancient) time goes on. Yet we should be wary of retrojecting this relationship too far into the past. It certainly does not go back as far as the seventh century BCE, when the title was still a novelty and the Diary was not yet conceptualised. One might be tempted to identify the Neo-Babylonian 'golden age' of the early sixth century as a possible starting point. Yet we should not discount the massive political, social and intellectual upheavals of ca. 650-61o BCE and ca. 520-470 BCE, brought about respectively by the collapse of the Assyrian empire and the Achaemenid reprisals against northern Babylonian revolts. These periods were so fundamentally catastrophic for the health of cuneiform intellectual culture that I have elsewhere described them as "survival bottlenecks". ${ }^{21}$ Over the course of the fifth and fourth centuries BCE, the temple communities of both Uruk and Babylon had to completely reinvent themselves and their relationships to the divine world, to (mostly absent) royal patronage, and to the increasingly diverse urban populations from whom they sought individual clients. In these uncertain times it became ever more important to construct and project an image of age-old constancy and conservatism, based on a nostalgic view of a past in which real kings truly

121 Robson (2018). 
valued — and supported—cuneiform scholarship. While much clearly did remain the same, it is increasingly apparent that just as much radically changed. We should thus be wary of allowing the invented traditions of the last centuries of cuneiform culture to overly influence our interpretations of what had gone before. Yet even if we are no closer to knowing the diarists by name, we now have a much clearer idea of their likely collective identity.

\section{References}

Ambos, C., forthcoming, "The History of the Cult of the Sky-god Anu in Uruk: Philological and Archaeological Evidence", in P. Cotticelli and V. Sadovski (eds), The Ritual Sphere and Royal Ideology in the Ancient Middle East.

Baker, H. D., 2008, "Babylon in 484 BC: The Excavated Archival tablets as a Source for Urban History', Zeitschrift für Assyriologie 98, 100-116.

Beaulieu, P.-A., 1991, “Neo-Babylonian Larsa: a Preliminary Study”, Orientalia 6o, 58-81.

Beaulieu, P.-A., 1993. "Prebendiers d'Uruk à Larsa", Revue d'Assyriologie 87, 137-152.

Beaulieu, P.-A., 1989, The Reign of Nabonidus, King of Babylon 556-539 BC (New Haven and London: Yale University Press).

Beaulieu, P.-A., 1995, "The Brewers of Nippur", Journal of Cuneiform Studies 47, 85-94

Beaulieu, P.-A., 20oo, "The Descendants of Sîn-lēqi-unninni", in J. Marzahn and H. Neumann (eds), Assyriologica et Semitica. Festschrift für Joachim Oelsner (Münster: Ugarit-Verlag), 1-16.

Beaulieu, P.-A., 2006, "The Astronomers of the Esagil Temple in the Fourth century BC", in A. K. Guinan et al. (eds), If a Man Builds a Joyful House: Assyriological Studies in Honor of Erle Verdun Leichty (Leiden: Brill), 5-22.

Beaulieu, P.-A. and Britton, J., 1994, "Rituals for an Eclipse Possibility in the 8th Year of Cyrus", Journal of Cuneiform Studies 46, 73-86.

Boiy, T., 2004, Late Achaemenid and Hellenistic Babylon (Leuven: Peeters).

Bongenaar, A. C. V. M, 1997, The Neo-Babylonian Ebabbar Temple at Sippar: its Administration and its Prosopography (Leiden: Nederlands Historisch-Archaeologisch Instituut te Istanbul). Brown, D., 2008. "Increasingly Redundant: the Growing Obsolescence of the Cuneiform Script in Babylonia from 539 BC", in J. Baines, J. Bennet and S. Houston (eds), The Disappearance of Writing Systems: Perspectives on Literacy and Communication (London: Equinox), 73-102. 
Clancier, P., 2007, "La Babylonie hellénistique: aperçu d'histoire politique et culturelle", Topoi. Orient-Occident, 15, 21-74.

Clancier, P., 2009, Les bibliothèques en Babylonie dans la deuxième moitié du I ${ }^{e r}$ millénaire av. J.-C. (Münster: Ugarit-Verlag).

Clancier, P., 2017, "The Polis of Babylon: An Historiographical Approach" in B. Chrubasik and D. King (eds.), Hellenism and the Local Communities of the Eastern Mediterranean, 400 BCE250 CE (Oxford: Oxford University Press), 53-82.

Clancier, P. and Monerie, J., 2014, "Les sanctuaires babyloniens à l'époque hellénistique. Évolution d'un relais de pouvoir", Topoi. Orient-Occident 19, 181-237.

Clay, A. T., 1923. Babylonian Records in the Library of J. Pierpont Morgan 4: Epics, Hymns, Omens, and Other Texts (New Haven: Yale University Press).

Corò, P., 2005, "Esorcisti e prebende dell'esorcista nella Babilonia di I millennio: il caso di Uruk", Studi Classici e Orientali 51, 11-24.

Da Riva, R., 2013a, "Nebuchadnezzar II's Prism (EK 7834): A New Edition", Zeitschrift für Assyriologie 103, 196-229.

Da Riva, R., 2013b, The Inscriptions of Nabopolassar, Amēl-Marduk and Neriglissar (Berlin: De Gruyter).

Dirven, L., 2014, "Religious Continuity and Change in Parthian Mesopotamia: a Note on the Survival of Babylonian Traditions", Journal of Ancient Near Eastern History 4, 1-29.

Fales, F. M., and Postgate, J. N., 1992, Imperial Administrative Records, Part I: Palace and Temple Administration, State Archives of Assyria, 7 (Helsinki: Helsinki University Press).

Fincke, J. C., 2010, "Astrologische Omenreporte aus Assur: Mondfinsternisse im Monat nisannu", in S. M. Maul and N. P. Heeßel (eds), Assur-Forschungen: Arbeiten aus der Forschungsstelle "Edition literarischer Keilschrifttexte aus Assur" der Heidelberger Akademie der Wissenschaften (Wiesbaden: Harrassowitz), 35-63.

Foster, B. R., 2005, Before the Muses: an Anthology of Akkadian Literature, 3rd edn (Bethesda, MA: CDL Press).

Fuchs, A., 2014, "Die unglaubliche Geburt des neubabylonischen Reiches, oder: die Vernichtung einer Weltmacht durch den Sohn eines Niemand", in M. Krebernik and H. Neumann (eds), Babylonien und seine Nachbarn (Münster: Ugarit-Verlag), 25-71. 
Gabbay, U., 2014a, Pacifying the Hearts of the Gods: Sumerian Emesal Prayers of the First Millennium BC, Heidelberger Emesal-Studien, 1 (Wiesbaden: Harrassowitz).

Gabbay, U., 2014b, "The kalû Priest and kalûtu Literature in Assyria", Orientalia 49, 115-144.

Gadd, C. J., and Kramer, S. N., 1966, Ur Excavations, Texts, VI: Literary and Religious Texts, Part Two (London: The British Museum).

George, A. R., 1991, "Tablets from the Folios of Sidney Smith, Part Two: Prognostic and Diagnostic Omens", Revue d'Assyriologie 85, 137-167.

George, A. R., 2010, "Xerxes and the Tower of Babel", in J. Curtis and S. Simpson (eds), The World of Achaemenid Persia: History, Art and Society in Iran and the Ancient Near East (London: I. B. Tauris), 471-48o.

Gray, J.M.K. and Steele, J. M., 20o8, "Studies on Babylonian Goal-year Astronomy I: A Comparison between Planetary Data in Goal-year Texts, Almanacs and Normal Star Almanacs", Archive for History of Exact Sciences 62, 553-600.

Hackl, J., 2013, "Materialien zur Urkundenlehre und Archivkunde der spätzeitlichen Texte aus Nordbabylonien", unpublished PhD dissertation, Universität Wien.

Hackl, J., 2017, "New Additions to the Rahimesu Archive: Parthian Texts from the British Museum and the World Museum Liverpool", in K. Kleber and R. Pirngruber (eds), Silver, Money and Credit. A Tribute to Robartus J. van der Spek (Leiden: Nederlands Instituut voor het Nabije Oosten), 87-106.

Hauser, S., 1999, "Babylon in arsakidischer Zeit", in J. Renger (ed.), Babylon: Focus Mesopotamischer Geschichte, wiege früher Gelehrsamkeit, Mythos in der Moderne (Saarbrücken: SDV), 207-23o.

Heeßel, N., 20o8, "Astrological Medicine in Babylonia", in A. Akasoy, C. Burnett, and R. YoeliTlalim (eds), Astro-medicine: Astrology and Medicine, East and West, Micrologus' Library, 25 (Florence: SISMEL-Edizioni del Galluzzo), 1-16.

Hunger, H., 1976, Spätbabylonische Texte aus Uruk, vol. 1 (Berlin: Mann).

Hunger, H., 1992, Astrological Reports to Assyrian Kings, State Archives of Assyria, 8 (Helsinki: Helsinki University Press).

Hunger, H., 1999, "Non-mathematical Astronomical Texts and their Relationships", in N. Swerdlow (ed.), Ancient Astronomy and Celestial Divination (Cambridge, MA: MIT Press), pp. $77-98$. 
Joannès, F., 1992, "Les archives de Ninurta-ahhêe-bulliț", in M. deJ. Ellis (ed.), Nippur at the Centennial: Papers Read at the 35e Rencontre Assyriologique Internationale, Philadelphia, 1988 (Philadelphia: The University Museum), 87-100.

Jursa, M., 2005, "Die Datierung des spätachämenidischen Wollpächterdossiers aus Nippur und das Ninurta-ahhē-bulliț-Archiv", NABU 2005/o6.

Jursa, M., 2007, 'Die Söhne Kudurrus und die Herkunft der Neubabylonischen Dynastie', Revue d'Assyriologie 101, 125-136.

Jursa, M., 2010a, Aspects of the Economic History of Babylonia in the First Millennium BC: Economic Geography, Economic Mentalities, Agriculture, the Use of Money and the Problem of Economic Growth (Münster: Ugarit-Verlag).

Jursa, M., 201ob, "Der neubabylonische Hof", in B. Jacobs and R. Rollinger (eds), Der Achämenidenhof/ The Achaemenid Court (Wiesbaden: Harrassowitz), 67-106.

Jursa, M., 2014, "The Lost State Correspondence of the Babylonian Empire as Reflected in Contemporary Administrative Letters", in K. Radner (ed.), State Correspondence in the Ancient World, from New Kingdom Egypt to the Roman Empire (Oxford: Oxford University Press), 94-111.

Kennedy, D. A., 1968, Babylonian Tablets in the British Museum, Vol. 49: Late-Babylonian Economic Texts (London: Trustees of the British Museum).

Kessler, K., 2004, "Urukäische Familien versus babylonische Familien: die Namengebung in Uruk, die Degradierung der Kulte von Eanna und der Aufstieg des Gottes Anu", Altorientalische Forschungen 31, 237-262.

Kleber, K., 2008, Tempel und Palast: die Beziehungen zwischen dem König und dem EannaTempel im spätbabylonischen Uruk (Münster: Ugarit-Verlag).

Kümmel, H. M., 1979, Familie, Beruf und Amt im spätbabylonischen Uruk: prosopographische Untersuchungen zu Berufsgruppen des 6. Jahrhunderts v. Chr. in Uruk (Berlin: Mann).

Lauinger, J., 2016, “Iqqur İpuš at Tell Tayinat”, Journal of Cuneiform Studies 6o, 229-248.

Livingstone, A., 2007, “The Babylonian Almanac: a Text for Specialists?”, in B. Groneberg and H. Spieckermann (eds), Die Welt der Götterbilder (Berlin: De Gruyter), 85-101.

Livingstone, A., 2013, Hemerologies of Assyrian and Babylonian Scholars, Cornell University Studies in Assyriology and Sumerology, 15 (Bethesda, MD: CDL Press). 
Luukko, M. and G. Van Buylaere, 2002, The Political Correspondence of Esarhaddon, State Archives of Assyria, 16 (Helsinki: Helsinki University Press.

Maul, S. M., 1994, Zukunftsbewältigung: eine Untersuchung altorientalischen Denkens anhand der babylonisch-assyrischen Löserituale (Namburbi) (Mainz: von Zabern).

McEwan, G. J. P., 1981, “Arsacid Temple Records", Iraq 43, 131-143.

Mitsuma, Y., 2015, "From Preliminary Diaries to Short Diaries: the First and Second Steps in the Compilation Process of the Late Babylonian Astronomical Diaries", SCIAMVS: Sources and Commentaries in Exact Sciences 16, 53-73.

Neugebauer, O., 1955. Astronomical Cuneiform Texts, 3 vols. (Berlin: Springer).

Neugebauer, O. and Sachs, A., 1968-69, "Some Atypical Astronomical Cuneiform Texts, II", Journal of Cuneiform Studies 22, 92-113

Nougayrol, J., 1947, "Petits texts religieux d'époque achéménide", Revue d’Assyriologie 41, 2942.

Oelsner, J., 2000, "Von Iqǐšâ und einigen anderen spätgeborenen Babyloniern”, in S. Graziani (ed.), Studi su vicino Oriente antico dedicati alla memoria di Luigi Cagni (Napoli: Istituto Universitario Orientale), 797-813.

Ossendrijver, M., 2011a, "Science in action: networks in Babylonian astronomy", in E. CancikKirschbaum, M. van Ess and J. Marzahn (eds.), Babylon: Wissenskultur in Orient und Okzident (Berlin: De Gruyter), 213-222.

Ossendrijver, M., 2011b, “Exzellente Netzwerke: die Astronomen von Uruk”, in G. J. Selz and K. Wagensonner (eds), The Empirical Dimension of Ancient Near Eastern Studies (Vienna: LIT), $631-44$.

Parpola, S., 1987, "The Forlorn Scholar", in F. Rochberg-Halton (ed.), Language, Literature, and History: Philological and Historical Studies Presented to Erica Reiner (New Haven, CT: The American Oriental Society), 257-278.

Parpola, S., 1993, Letters from Assyrian and Babylonian Scholars, State Archives of Assyria, 10 (Helsinki: Helsinki University Press).

Pinches, T. G., 1896, "A Babylonian Tablet Dated in the Reign of Aspasine", Babylonian and Oriental Record 4, 131-135.

Pirngruber, R., 2017, The Economy of Late Achaemenid and Seleucid Babylonia (Cambridge: Cambridge University Press). 
Postgate, J. N., 2007, "The Invisible Hierarchy: Assyrian Military and Civilian Administration in the 8th and 7th Centuries BC", in The Land of Assur and the Yoke of Assur: Studies on Assyria, 1971-2005 (Oxford: Oxbow), pp. 331-36o.

Radner, K., 2009, "The Assyrian King and his Scholars: the Syro-Anatolian and the Egyptian Schools", in M. Luukko, S. Svärd and R. Mattila (eds), Of God(s), Trees, Kings, and Scholars: Neo-Assyrian and Related Studies in Honour of Simo Parpola (Helsinki: Finnish Oriental Society), 221-38.

Radner, K. and Baker, H. D. (eds), 1998-2011, The Prosopography of the Neo-Assyrian Empire, 4 vols (Helsinki: Helsinki University Press).

Reiner, E., 1984, Your Thwarts in Pieces, Your Mooring Rope Cut: Poetry from Babylonia and Assyria (Michigan: The Horace H. Rackham School of Graduate Studies at the University of Michigan).

Reisner, G., 1896, Sumerisch-Babylonische Hymnen nach Thontafeln griechischer Zeit (Berlin: Spemann).

Robson, E., 2007, "Secrets de famille: prêtre et astronome à Uruk à l'époque hellénistique", in C. M. Jacob (ed.), Les lieux de savoir, I: Lieux et communautés (Paris: Albin Michel), 440-461. Robson, E., 2008, Mathematics in Ancient Iraq: a Social History (Princeton and Oxford: Princeton University Press).

Robson, E., 2011a, "Empirical Scholarship in the Neo-Assyrian Court", in G. Selz and K. Wagensonner (eds), The Empirical Dimension of Ancient Near Eastern Studies (Vienna: LIT), 6о3-3о.

Robson, E., 2011b, “The Production and Dissemination of Scholarly Knowledge”, in K. Radner and E. Robson (eds), The Oxford Handbook of Cuneiform Culture (Oxford: Oxford University Press), $557-76$.

Robson, E., 2014, "Tracing Networks of Cuneiform Scholarship with Oracc, GKAB and Google Earth", in M. Rutz and M. Kersel (eds), Archaeologies of Text: Archaeology, Technology and Ethics. Joukowsky Institute Publications, 4 (Oxford: Oxbow Books), 142-63.

Robson, E., 2017, “The Socio-economics of Cuneiform Scholarship after the 'End of Archives': Views from Borsippa and Uruk", in Y. Heffron, A. Stone and M. Worthington (eds), At the Dawn of History: Ancient Near Eastern Studies in Honour of J. N. Postgate (Winona Lake: Eisenbrauns), 455-470. 
Robson, E., 2018, “Do Not Disperse the Collection!' Motivations and Strategies for Protecting Cuneiform Scholarship in the First Millennium BC, in M. Popović, L. Roig Lanzillotta and C. Wilde (eds), Sharing and Hiding Religious Knowledge in Early Judaism, Christianity, and Islam (Berlin and Boston: De Gruyter), 8-45.

Robson, E., forthcoming Ancient Knowledge Networks: Social Geographies of Cuneiform Scholarship (London: University College Press).

Robson, E., M.-F. Besnier, P. Clancier, G. Cunningham, F. Reynolds, S. Tinney and G. Van Buylaere, 2007-12, The Corpus of Ancient Mesopotamian Scholarship: The Geography of Knowledge in Assyria and Babylonia, http://oracc.org/cams/gkab/corpus [accessed 1 December 2016].

Rochberg, F., 1998, Babylonian Horoscopes (Philadelphia: American Philosophical Society).

Rochberg, F., 200o, "Scribes and Scholars: the țupšar Enūma Anu Enlil", in J. Marzahn and H. Neumann (eds), Assyriologica et Semitica: Festschrift für Joachim Oelsner, Alter Orient und Altes Testament, 252 (Münster: Ugarit-Verlag), 359-376.

Rochberg, F., 2004, The Heavenly Writing: Divination, Horoscopy, and Astronomy in Mesopotamian Culture (Cambridge: Cambridge University Press).

Schaudig, H., 2001, Die Inschriften Nabonids von Babylon und Kyros' des Großen (Münster: Ugarit-Verlag).

Sciandra, R., 2012, "The Babylonian Correspondence of the Seleucid and Arsacid Dynasties: New Insights into the Relations between Court and City during the Late Babylonian Period", in G. Wilhelm (ed.), Organization, Representation and Symbols of Power in the Ancient Near East (Winona Lake: Eisenbrauns), 225-48.

Slotsky, A., 1998, The Bourse of Babylon: Market Quotations in the Astronomical Diaries of Babylonia (Bethesda, MD: CDL Press).

Spar, I. and W. G. Lambert (eds), 2005, Literary and Scholastic Texts of the First Millennium $B C$. Cuneiform Texts in the Metropolitan Museum of Art 2 (New York: The Metropolitan Museum of Art).

van der Spek, R. J., 1985, "The Babylonian Temple during the Macedonian and Parthian Domination", Bibliotheca Orientalis 42, 541-62. 
van der Spek, R. J., 2003, "Darius III, Alexander the Great and Babylonian Scholarship”, in W. Henkelman and A. Kuhrt (eds), A Persian Perspective: Essays in Memory of Heleen SancisiWeerdenburg (Leiden: Nederlands Instituut voor het Nabije Oosten), 289-346.

van der Spek, R. J., 2008, "Berossus as a Babylonian Chronicler and Greek Historian", in R. J. van der Spek et al. (eds.), Studies in Ancient Near Eastern World View and Society (Bethesda: CDL Press), $277-318$

Steele, J. M., 2000, "Eclipse Prediction in Mesopotamia", Archive for the History of Exact Sciences 54, 421-454.

Steele, J. M., 2016, “The Circulation of Astronomical Knowledge between Babylon and Uruk”, in J. M. Steele (ed.), The Circulation of Astronomical Knowledge in the Ancient World (Leiden: Brill), 83-118.

Stevens, K., 2013, "Secrets in the Library: Protected Knowledge and Professional Identity in Late Babylonian Uruk", Iraq 75: 211-253.

Stolper, M., 1988, “The šaknu of Nippur”, Journal of Cuneiform Studies 40, 127-155.

Stolper, M., 2007, “'Iranica in Post-Achaemenid Babylonian Texts”, in P. Briant and F. Joannès (eds), La transition entre l'empire achéménide et les royaumes hellénistiques, vers 350-30o av. J.C., Persika, 9 (Paris: De Boccard), pp. 223-26o.

Thureau-Dangin, F., 1922, Tablettes d'Uruk à l'usage des prêtres du temple d'Anu au temps des Séleucides, Textes Cunéiformes du Louvre, 6 (Paris: Geuthner).

Van Buylaere, G., 2010, "The Role of the hazannu in the Neo-Assyrian Empire”, in L. Kogan et al. (eds), Proceedings of the 53e Rencontre Assyriologique Internationale, Vol. 2: City Administration in the Ancient Near East, Babel und Bibel, 5 (Winona Lake: Eisenbrauns), 229246.

Villard, P., 1998a, "Akkullānu, astrologue, prêtre et juge", $N A B U$ 1998/52.

von Weiher, E., 1982, Spätbabylonische Texte aus Uruk, vol. 2 (Berlin: Mann).

von Weiher, E., 1988, Spätbabylonische Texte aus Uruk, vol. 3 (Berlin: Mann.)

von Weiher, E., 1993. Spätbabylonische Texte aus Uruk, vol. 4 (Mainz: von Zabern).

von Weiher, E., 1998, Spätbabylonische Texte aus Uruk, vol. 5 (Mainz: von Zabern).

Waerzeggers, C., 2003/04, "The Babylonian Revolts against Xerxes and the 'End of Archives"”, Archiv für Orientforschung 50, 150-173. 
Waerzeggers, C., 2011, "The Babylonian Priesthood in the Long Sixth Century BC", Bulletin of the Institute of Classical Studies 54, 59-70.

Wallenfels, R., 2017, "The Office Seal of the Šatammu of E-sangil during the Hellenistic Period: a Résumé", $N A B U$ 2017/21.

Wee, J. Z., 2016, "Virtual Moons over Babylonia: The Calendar Text System, its Micro-Zodiac of 13, and the Making of Medical Zodiology", in J. M. Steele (ed.), The Circulation of Astronomical Knowledge in the Ancient World (Leiden: Brill), 139-229.

Westbrook, R., 2005, "Patronage in the Ancient Near East", Journal of the Economic and Social History of the Orient 48, 210-233.

Wiseman, D. J. and Black, J. A., 1996, Literary Texts from the Temple of Nabû, Cuneiform Texts from Nimrud, 4 (London: British School of Archaeology in Iraq). 